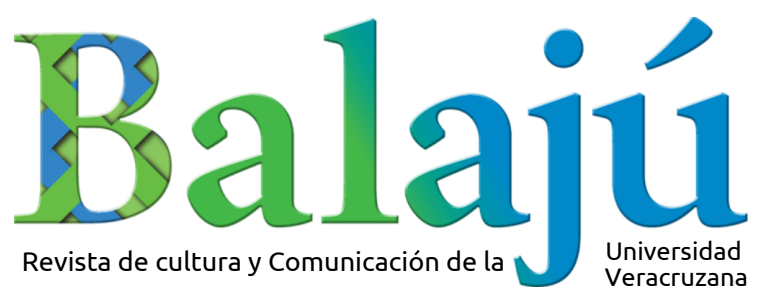

\title{
De El Dictamen al mundo: el periplo de las primeras fotografías del terremoto de 1920
}

\author{
Pere Freixa y Mar Redondo \\ Universitat Pompeu Fabra | Universitat de Barcelona \\ Recibido: 16-08-2020 | Aprobado: 17-02-2021
}


De El Dictamen al mundo: el periplo de las primeras fotografías del terremoto de 1920

From El Dictamen to the world: The Journey of the First Photographs of the 1920 Earthquake

Pere Freixa ${ }^{1} \mid$ Mar Redondo $^{2}$

\section{Resumen}

El día 3 de enero de 2020 se cumplió el centenario del terremoto que arrasó un amplio territorio entre los estados de Puebla y Veracruz. Oficialmente se contabilizaron 650 víctimas mortales, así como numerosos afectados. Fue el primer temblor ampliamente narrado mediante imágenes fotográficas en la prensa nacional. Este artículo utiliza el estudio de caso para analizar cómo los periódicos empezaron a incorporar imágenes fotográficas en sus páginas, de qué forma esas fotografías circularon, así como su función en la prensa y su significación para construir el relato visual de la catástrofe. Se constata el uso de la imagen para validar las informaciones escritas, la incipiente transformación del rol del fotoperiodista, que empieza a adquirir notoriedad, la existencia de las agencias en el mercado de la imagen y la presencia de intermediarios que facilitan el tránsito de las fotografías a nivel internacional. La investigación confirma la autoría del fotógrafo que realizó las primeras imágenes publicadas del temblor: Manuel Jiménez, de Xalapa, y el medio, El Dictamen, del puerto de Veracruz. Palabras clave: Fotografía de catástrofes, fotografía de prensa, terremotos, Xalapa, Veracruz, El Dictamen.

\section{Abstract}

January 3,2020, marked the centenary of the earthquake that demolished a wide swathe of territory in the Mexican states of Puebla and Veracruz, with official counts showing 650 fatalities and many more people affected by the disaster. It was also the first to be widely reported in the national press by means of photographic images. This article approaches the 1920 quake as a case study to analyse how newspapers began to incorporate photographic images, the ways in which these images circulated, their function in the media and in constructing a visual narrative of the catastrophe. It shows the use of the image to validate written information, the incipient transformation of the role of news photographer -a role then beginning to gain notoriety-, the existence of agencies in the image market and the presence of intermediaries that facilitated the international circulation of the photographs. The investigation confirms the identity of the photographer who took the first published images of the earthquake: Manuel Jiménez, of Jalapa, and the medium, El Dictamen, of Veracruz.

Keywords: Disaster photography, press photography, earthquakes, Jalapa, Veracruz, El Dictamen.

\footnotetext{
${ }^{1}$ Depto. de Comunicación, Universitat Pompeu Fabra, ORCID: 0000-0002-9199-1270, pere.freixa@upf.edu

${ }^{2}$ Depto. de Artes Visuales, Universitat de Barcelona, ORCID: 0000-0002-0000-8593, redondo@ub.edu
} 


\title{
De El Dictamen al MUNDO: El PERIPLO DE LAS PRIMERAS FOTOGRAFÍAS DEL TERREMOTO DE 1920
}

\author{
Pere Freixa \\ Mar Redondo
}

\section{Presentación}

En la noche del 3 de enero de 1920, un importante terremoto con epicentro en la población de Quimixtlán, en el estado de Puebla, arrasó parte de los estados de Veracruz y Puebla. El informe del Instituto Geológico de México describe de este modo el temblor: "El megasismo tuvo lugar a las 9h., 48m., 03s., (tiempo local del Observatorio Astronómico de Tacubaya) el día 3 de enero de 1920. Fue de carácter impetuoso y causó numerosos desastres en los cantones de Jalapa, Coatepec, Huatusco, Córdoba, Orizaba y Jalancingo, del Estado de Veracruz, y en el Distrito de Chalchicomula del de Puebla" (Salazar Salinas, 1922: 6). Fue conocido como el temblor de Xalapa. ${ }^{3}$ La virulencia del sismo, las réplicas posteriores, las sacudidas y los movimientos de tierra que causó provocaron oficialmente 650 muertes, debidas mayoritariamente a los lodos desbordados del río Huitzilapan. ${ }^{4}$ Los desperfectos fueron importantes y algunas poblaciones de la cordillera quedaron sepultadas. Otras fuentes contemporáneas, como Luna Bauza (1994), quien fuera jefe de la estación sismológica de la UNAM, afirman que el episodio sísmico provocó más de 3000 muertes, a pesar de que los medios de la época llegaron a hablar de 4000 muertos y más de 7000 damnificados. $^{5}$

\footnotetext{
${ }^{3}$ Los estudios de sismología desarrollados posteriormente al gran temblor de México, de 1985, afianzan el sobrenombre de "temblor de Jalapa" para referir el terremoto de 1920. Por ejemplo, en Suárez (1991) y en Singh y Ordaz (1994). [Aunque en la época bajo consideración se escribía comúnmente el nombre de la ciudad con J, también aparece a veces la -hoy oficial-X; por eso en el artículo aparece tanto "Jalapa" como "Xalapa". N. de la E.]

${ }^{4}$ La cifra de 650 fallecidos la aporta el informe del Instituto Geológico de México. Posteriormente la ratifican otros autores, basándose en dicho informe, como en Mora y Murrieta (1995), Lermo et al. (1995) y, recientemente, Ayala-Flores (2019).

${ }^{5}$ La prensa de la época contabilizó un número de fallecimientos y afectados superior a 3000 personas. Los periódicos y las agencias de noticias llegaron a hablar de hasta 10000 víctimas: "En la Secretaría de Gobernación se informó hoy que, según noticias oficiales enviadas a ese Ministerio, el número de víctimas ocasionadas por los temblores en la zona volcánica de Perote y Pico de Orizaba, llegan ya a diez mil, y que es probable que pasen de esa suma" (Dictamen, 9 de enero 1920, p. 6.). Las informaciones llegaron también a la prensa internacional. En España, diversos periódicos recogen la noticia. Así, por ejemplo, $A B C$ indica que: "Oficialmente se confirma que se elevan a 3000 las víctimas a consecuencia de los terremotos" ( $A B C$, 9 de enero 1920, p. 17) y, posteriormente, dos días más tarde, corrige los datos: "Entre muertes y heridos ascienden las víctimas al número de 7000 " $(A B C$, 11 de enero de 1920, p. 22). El Fígaro reporta el mismo día idéntica cifra: "Entre muertos y heridos ascienden las víctimas al número de 7 000" (Fígaro, 11 de enero de 1920, p. 11). También El Imparcial informa sobre los damnificados y cita como fuente a la Agencia Americana. En Estados Unidos, El Tucsoniense del día 13 de enero
} 
El terremoto de 1920 dio lugar por primera vez en el país al registro y la retrasmisión fotográfica de la catástrofe en la prensa. Junto con las tragedias acaecidas en San Francisco (1906), Valparaíso (1906), Messina (1908), París (1910), Avezzano (1915) y Tokio (1923), conforman los primeros acontecimientos catastróficos narrados de forma popular y masiva por medio de imágenes fotográficas, tanto en periódicos como por medio de tarjetas postales. En México, el sismo de 1920 es, efectivamente, el primer desastre natural de gran envergadura ampliamente fotografiado y relatado visualmente, que contó con cobertura mediática tanto a nivel nacional como internacional. ${ }^{6}$

Los días inmediatamente posteriores al terremoto, los medios acompañaron sus textos con infografías -sobre todo mapas- y fotografías de archivo de los lugares afectados por los temblores. En cuanto empezaron a llegar a las redacciones las primeras fotografías capturadas en los lugares siniestrados, fueron publicándolas paulatinamente, de forma continuada, iniciando de este modo la que puede considerarse como la primera retrasmisión visual de un terremoto en México. ${ }^{7}$

El periódico El Dictamen, del puerto de Veracruz, fue el primer medio en publicar fotografías del temblor. El 9 de enero, solo seis días después del suceso, presentó en portada una imagen en la que se podía apreciar los trabajos de rescate de cadáveres de las aguas del río La Antigua que estaban realizando las autoridades y vecinos en San Francisco de las Peñas, actual José Cardel. La leyenda de la fotografía describía la gravedad y el dramatismo de la situación: "En la fotografía que publicamos -primera que llega a Veracruz tomada en la región

cifró en 4000 el número de muertos: "Más de 4000 son ya los muertos y los daños en la propiedad siguen aumentando en millones de pesos" (Tucsoniense, 13 de enero de 1920, p. 1.), y La Prensa, de San Antonio, tituló: "A siete mil se hace ascender el número de muertos que ha habido" (Prensa, 11 de enero de 1920, p. 1). Actualmente, con motivo del centenario del temblor, varios medios han realizado reportajes especiales sobre el terremoto; por ejemplo, el reportaje que El Universal publicó con motivo del centenario (Ramírez, 2019), en el que se mantiene el número de 3000 víctimas y afectados.

${ }^{6}$ Un terremoto anterior, de 1912, conocido como el de Acambay, contó con seguimiento periodístico por parte del diario El Imparcial. Entre los días 20 y 29 de noviembre publicaron ocho fotografías, reproducidas en semitonos aún bastante rudimentarios. La cobertura gráfica de El Imparcial puede considerarse un antecedente importante de lo que fue el tratamiento fotográfico dado al sismo de 1920, ampliamente reproducido por medio de fotografías por parte de todos los periódicos de la época y en tarjetas postales. Como apunta Acacia Maldonado: "Antes de 1910 los diarios informativos habían hecho escaso uso de la fotografía porque muy pocos tenían la tecnología necesaria (rotativas de gran tiraje y de medio tono) y resultaba difícil publicar imágenes diariamente, a diferencia de los semanarios que tenían más tiempo para preparar la edición” (Maldonado, 2005: 175).

${ }^{7}$ Por su enorme dimensión, por darse en un entorno urbano y, sobre todo, por el enorme número de víctimas que ocasionaron, se consideran los terremotos de San Francisco (1906) y Messina (1908) como los dos principales referentes en lo que se refiere a la comunicación visual de una catástrofe natural (Taylor, 2016). En ambos casos se publicaron amplios reportajes en la prensa y se editaron centenares de tarjetas postales que se reeditaron numerosas veces y se mantuvieron en el mercado varios años después de la catástrofe. Durante las primeras décadas del siglo XX, los temas de actualidad resultaron un motivo visual recurrente en las tarjetas postales por su elevada demanda y frecuente reedición (Riego, 2010). 


\section{Balajú}

damnificada por los terremotos- puede verse la labor de los vecinos de San Francisco que se ocupan de rescatar cadáveres a las turbulentas aguas del río que arrastran en su corriente restos de casas y despojos humanos" (Dictamen, 9 de enero de 1920, p. 1).

Dos días después, el 11 de enero, mostraba nuevamente en portada fotografías del terremoto. Esta vez se trataba de una elaborada composición visual que incluía cinco imágenes enmarcadas por la composición del grafista del periódico, el Sr. Urbina. En la leyenda se reivindicaba la labor desarrollada por el periódico para proveer a los lectores de informaciones exclusivas: "El esfuerzo que ha hecho EL DICTAMEN para proporcionar a sus lectores una amplísima información de los desgraciados sucesos ocurridos en la zona volcánica de Veracruz, nos ha valido la satisfacción de ser los primeros en publicar noticias recogidas en el mismo lugar de los acontecimientos y las primeras fotografías que, venciendo un sinnúmero de dificultades, logramos obtener". (Dictamen, 11 de enero de 1920, p. 1).

Significativamente, la mayor expresión del relato gráfico se produjo los fines de semana, aprovechando el mayor tiraje de ejemplares. ${ }^{8}$ Es cuando realmente se puede considerar que empezó la publicación de reportajes fotográficos realizados tanto por los fotógrafos de Xalapa y de Veracruz como por los enviados especiales de los periódicos de la Ciudad de México. En total, El Dictamen publicó, durante el mes de enero de 1920, 39 imágenes relacionadas con el sismo, 34 fotografías y 5 gráficos. En el mismo periodo, El Universal, de Ciudad de México, mostró 40 imágenes, 31 de ellas en un solo día, en un amplio reportaje impreso el domingo 18 de enero. Por su parte, el diario Excelsior, también de Ciudad de México, publicó 49 fotografías y 5 ilustraciones. De las 49 fotografías, 20 correspondieron a tomas realizadas en el lugar de los acontecimientos y 15 fueron retratos de personajes relacionados con las colectas y los actos de beneficencia en favor de los damnificados. Las 14

\footnotetext{
${ }^{8}$ Desde principios de siglo, la prensa venía ofreciendo reportajes fotográficos por medio de los semanarios ilustrados. El Mundo Ilustrado, Semanario Literario Ilustrado y El Tiempo Ilustrado son buena muestra de los periódicos que se publicaban en la capital (Escorza-Rodríguez, 2015). Sin embargo, en lo que se refiere a la prensa diaria, no puede considerarse hasta mediados de la década de los veinte el paso de lo que, autores clásicos como Hicks, definen como la transición de un modelo periodístico textual a otro visual: "Los cambios fundamentales en el pensamiento de los editores, junto con los avances mecánicos de la cámara, tuvieron efectos revolucionarios en la producción y el uso de la fotografía periodística en los años 1925 a 1935" (Hicks, 1952: 20). La prensa diaria reservaba la publicación de reportajes fotográficos a las ediciones dominicales que se acompañaban con complementos gráficos. En palabras de Barnhurst y Nerone: "La prensa diaria de la época estableció una especie de apartheid, en el que el texto y las imágenes coexistían como contenidos separados, pero (quizás) iguales. Durante este período, el medio tono se convirtió en una realidad práctica, aunque las imágenes por lo general no podían capturar más que una sola toma de escenas estáticas o poses rígidas de personas. Para su publicación, las imágenes fueron separadas en espacios delimitados por cercas, líneas, bordes y decoraciones" (Barnhurst y Nerone, 2001: 141).
} 


\section{Balajú}

fotografías restantes eran imágenes de archivo que se mostraron durante los primeros días para ubicar los territorios afectados.

El número de fotografías, la variedad y la amplitud temática, así como la competencia que se generó entre los medios impresos permiten considerar el terremoto de 1920 como la primera catástrofe natural acaecida en México que contó con una efectiva cobertura mediática. Por primera vez el relato visual trasladaba a los lectores por medio de fotografías la dimensión de la tragedia, ponía rostro a los protagonistas y a las víctimas anónimas. También por primera vez los reportajes visuales del seísmo cruzaron las fronteras nacionales y se distribuyeron entre los medios internacionales, sobre todo en Estados Unidos de América y, más escasamente, en Europa.

En este artículo se resigue la trayectoria de dos fotografías del periódico El Dictamen de Veracruz: la primera imagen publicada del terremoto que el rotativo ofreció en la portada del día 9 de enero de 1920, y una de las cinco fotografías que aparecieron también en portada el día 11 de enero. Ambas fueron tomadas en la zona afectada días antes de su publicación, y viajaron hasta Veracruz para convertirse en fotograbados de semitono. Ambas imágenes tuvieron un recorrido excepcional durante las semanas posteriores al primer temblor y adquirieron un papel determinante en la creación del relato visual del seísmo, conocido popularmente como temblor de Xalapa. Ambas imágenes las realizó el fotógrafo xalapeño Manuel Jiménez. La reseña de su publicación permite no solamente observar la existencia de una incipiente fotografía periodística sino también cómo el modelo de información basado en el relato textual permanece a inicios de la década de los veinte, a pesar de haberse iniciado su transformación como resultado de la incorporación de las imágenes fotográficas. ${ }^{9}$

\section{Objetivos y metodología}

\footnotetext{
${ }^{9}$ En la llamada cultura tipográfica, el reportero describe los acontecimientos con la intención de que los lectores sientan que están en el escenario de la acción. Es característico del periodo el uso de recursos narrativos como las llamadas descripciones a pie, relatos efectuados en primera persona que describían una escena como si fuera contada por un espectador que recorriera el lugar de los hechos. Era común la construcción de narraciones largas, tratadas como escenas de una novela contemporánea. Estas se completaban con descripciones extensas de los estados emocionales de los personajes presentes en la escena, tratando de transmitir la fuerza emocional de detalles significativos (Barnhurst y Nerone, 2001). La publicación de fotografías, normalmente en un momento posterior al relato literario de los hechos se realiza como manifestación de veracidad, como forma de validar el contenido presentado con anterioridad en el texto.
} 


\section{Balajú}

La investigación que se ha llevado a término se sustenta en preguntas de investigación específicas sobre el medio fotográfico y sus prácticas en el registro y la configuración de relatos visuales relacionados con las catástrofes. Inundaciones, incendios, terremotos o tsunamis, por citar solamente las más devastadoras, aniquilan por sorpresa y a menudo de forma imprevisible grandes territorios y a sus pobladores. En el caso específico de México, el relato histórico de los sismos que han asolado el país se remonta a la tradición documental prehispánica (por ejemplo, Orozco, 1887; Sugawara, 1987), aunque es a partir del siglo XIX cuando se empieza a tener importantes crónicas de las catástrofes por medio de la documentación oficial, los informes técnicos y el relato periodístico (Figueroa, 1970; Singh y Ordaz, 1994). No será sin embargo hasta el siglo XX cuando la información y la crónica de los acontecimientos se construirá a través de mensajes visuales, primero en forma de fotografías $y$, posteriormente, de registros videográficos.

Las preguntas de investigación se basan en la hipótesis de que es con el temblor de enero de 1920 cuando la prensa mexicana construye por primera vez un discurso fotográfico para narrar el suceso catastrófico. Se elabora entonces un constructo visual con autonomía discursiva que se presenta principalmente en los medios en diálogo con el relato periodístico. ¿Cómo son las imágenes que se realizan del temblor? Si se asume que nunca se había dado cobertura fotográfica a un evento de esa índole, podemos preguntarnos cuáles son los criterios -conceptuales, formales, informativos-que siguen los autores de las imágenes. ¿Qué muestran estas fotografías? ¿Dónde se realizan? Y también cabe interrogarse acerca de quién las realiza y cómo se distribuyen para que finalmente las publique un periódico y lleguen a la ciudadanía. ¿Qué recorrido tienen? ¿Cuál es la vida de esas imágenes?

Se parte también de la hipótesis de que la publicación de las imágenes del sismo de 1920 pone de manifiesto el proceso de transformación del modelo periodístico. El estudio tiene como objetivo secundario la observación, a partir del estudio de caso, de las fases iniciales del proceso de transformación de un modelo de periodismo basado en el texto a otro visual. Para llevar a cabo estos objetivos, la investigación se ha focalizado en reseguir un número muy reducido de fotografías del terremoto, las primeras publicadas por el periódico El Dictamen, que fueron las primeras que se visualizaron en México. La reducción del objeto de estudio a unos casos muy específicos permite explorar ampliamente el acontecer de ese objeto y sus múltiples dimensiones, poner de relieve las incipientes praxis profesionales en el ámbito de la comunicación que se estaban creando en México durante esos años. Permite observar cómo se 


\section{Balajú}

construye el relato textual en la prensa y cómo posteriormente la fotografía es incorporada o bien con el fin de validar la narrativa o como contenido paralelo. Se ha revisado la prensa nacional del periodo en la hemeroteca Lerdo de Tejada y en la Hemeroteca Nacional. Se han consultado los medios internacionales, sobre todo norteamericanos y españoles, en la Biblioteca Nacional de España y en la Library of Congress. Finalmente se ha elegido centrar el estudio en tres periódicos, por su relevancia en la época y por el gran volumen de imágenes que publicaron: El Dictamen, de Veracruz, y El Universal y Excelsior, de Ciudad de México.

A nivel metodológico se ha utilizado el estudio de caso (Stake, 1995; Yin, 2013) como sistema de investigación documental que permite esclarecer microhistorias y estructuras subyacentes en los procesos sociales y comerciales de un determinado momento histórico. Con este método no se pretende la descripción general o completa ni la sistematización del objeto de estudio. El recorrido por el devenir de las imágenes permite asignar multidimensionalidad a la fotografía convertida en el objeto de estudio de la investigación. Las imágenes posibilitan el análisis iconológico en la aceptación de que son portadoras de un contenido autoral reconocible e interpretable en tanto que texto visual. Las fotografías percibidas como producto informacional devienen objeto de intercambio que muta de significado en función de su reubicación comercial. A la vez, como testimonio de un determinado contexto histórico-social, las fotografías concretas, singulares, vinculadas a un lugar-tiempo fotográfico, resultado de pulsiones, decisiones y azares, se transforman en objetos que van asumiendo la carga de valores y connotaciones, convirtiéndose en el proceso en portadoras de significados simbólicos. 


\section{Balajú}

\section{El rescate de cadáveres en San Francisco de las Peñas}

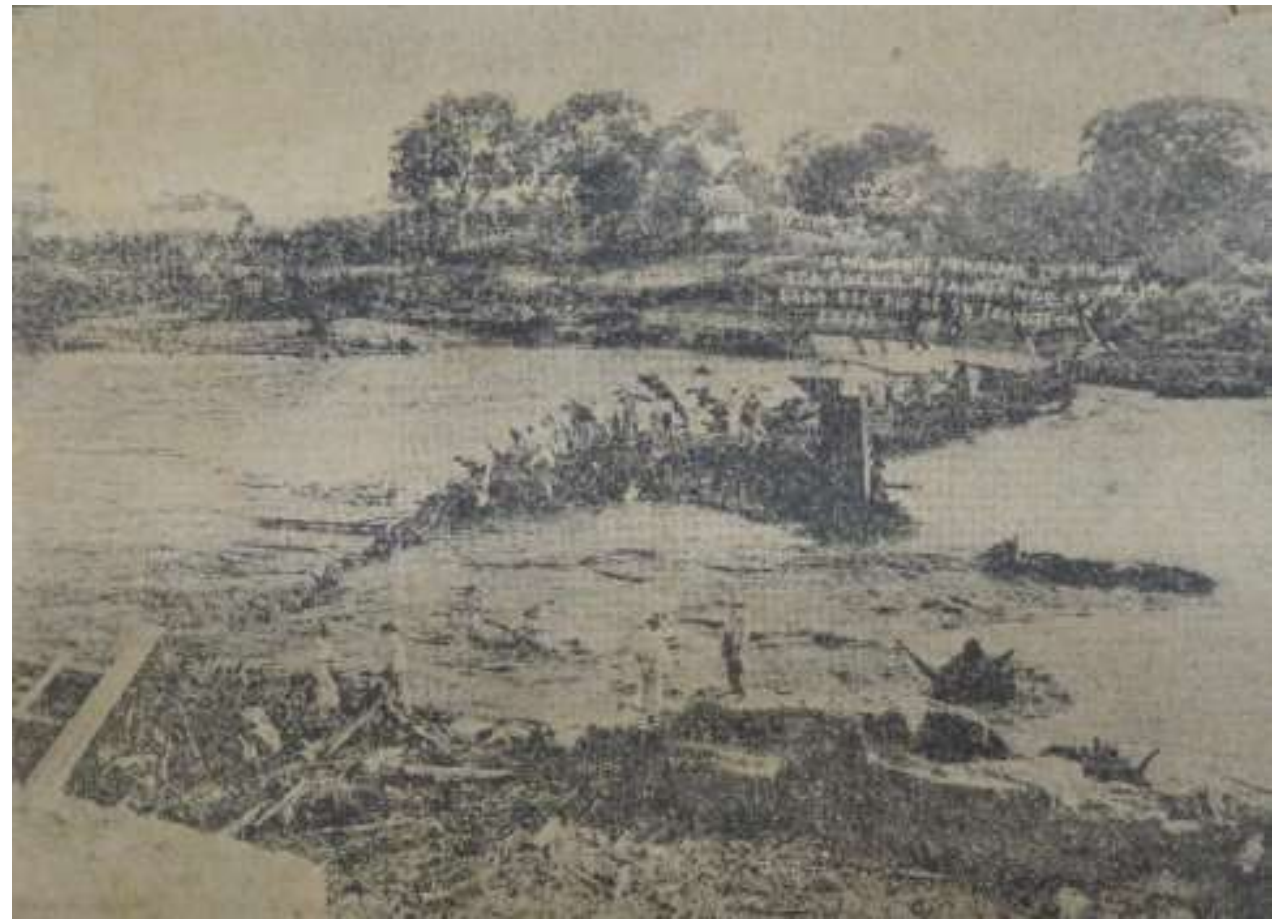

FIGURA 1. Rescate de cadáveres y restos humanos en una empalizada creada en el río La Antigua, en José Cardel. Fotografía atribuida a Manuel Jiménez. Fuente: El Dictamen, 9 enero de 1920, p. 1, Hemeroteca de El Dictamen, Puerto de Veracruz.

El día 9 de enero, seis días después de que el seísmo azotara la zona afectada, $E l$ Dictamen publicó en portada la imagen que se reproduce (figura 1). El pie de página añadía datos que completaban lo que la fotografía reproducía toscamente: "Representa una empalizada formada con objeto de que en ella se detengan los cadáveres, para extraerlos. Las personas que están dedicadas a esta piadosa misión llevan cubiertas boca y nariz con pañuelos para librarse un tanto de la aspiración directa de los gases mefíticos que se desprenden de las aguas putrefactas" (El Dictamen, 9 de enero de 1920, p. 1). Sobre la imagen, el fotógrafo había anotado el siguiente texto: "El presidente municipal en unión del pueblo desalojando la palizada del río de San Francisco de barro".

La fotografía no ofrecía novedad respecto de acontecimientos ya narrados textualmente, pero permitía mostrar a los lectores la certeza visual respecto a lo publicado hasta entonces. La crónica de los acontecimientos acaecidos en el río de San Francisco ${ }^{10}$ se había iniciado tres días

\footnotetext{
${ }^{10}$ El río de San Francisco de las Peñas, descrito por la prensa, corresponde al tramo del río La Antigua a su paso por José Cardel. El río recoge las aguas de los ríos Huitzilapan (Coatepec, Xico y Teocelo), Xalatla (Cosautlán)
} 


\section{Balajú}

antes. El martes 6 de enero, El Dictamen abrió en primera página con la noticia titulada "Cadáveres recogidos y que eran arrastrados por las aguas". Se explicaba que desde el día anterior se venían realizando tareas de rescate de cadáveres: "El río de San Francisco continuó arrastrando ayer cadáveres y miembros humanos lo mismo que despojos de casas destruidas. Varios fueron los cadáveres recogidos allí, entre ellos el de una niña de corta edad" ( $E l$ Dictamen, 6 de enero de 1920, p. 1). Por orden de las autoridades, se daba sepultura a los cuerpos y restos recopilados en el mismo lugar donde eran recogidos.

El horror de la magnitud de la escena se repitió los días siguientes. El miércoles día 7, en la página 5, bajo el título "Macabra recolección de cadáveres", continuaba la información del suceso. En el texto se mencionaba la creación de empalizadas para la recolección de los muertos: "El Presidente Municipal de este lugar auxiliado por empleados del Ayuntamiento y del cuerpo de Policía destacaron hoy setenta y cinco hombres a lo largo del río San Francisco y en varias partes de la ribera de este para recoger los cadáveres que fueron arrastrados por las aguas $[. .$.$] apostadas en diversos lugares construyeron empalizadas para detener los despojos$ humanos que todo el día de hoy estuvo arrastrando la corriente del río" (El Dictamen, 7 de enero de 1920, p. 5). En la descripción de los hechos se refería el olor insoportable que desprendían las aguas, así como la presencia de restos de casas, animales y humanos; "el espectáculo es verdaderamente espantoso". Se daba fe también del rescate de unos cincuenta cadáveres, algunos de ellos de soldados, la mayoría fuertemente mutilados, en otras zonas del río.

Al día siguiente, 8 de enero, en la noticia titulada "Después del terror", se aludía nuevamente a la intervención de las autoridades en la creación de las empalizadas: "El presidente municipal, Sr. Lino Lara y los señores H. Hernández y Adalberto Terán, miembros del Ayuntamiento de esta población, en unión del Juez Municipal y del Inspector General de Policía, han emprendido la tarea de construir palizadas para recoger despojos humanos" ( $E l$ Dictamen, 8 de enero de 1920, p. 7).

La fotografía publicada el viernes 9 de enero supone la verificación visual de las informaciones difundidas por el periódico. La imagen, a pesar de la poca nitidez que muestra y la escasa resolución, pone de manifiesto la verosimilitud del relato. ${ }^{11}$

\footnotetext{
y Tlilapa (Ixhuacán) (Pereyra, Pérez y Salas, 2010), poblaciones de las que podrían proceder los cuerpos y restos humanos arrastrados por las aguas.

${ }^{11}$ La técnica de los semitonos utilizada en la prensa en esos años para la reproducción de fotografías resultaba especialmente crítica en la reproducción de planos generales con poco contraste, como sucede en la fotografía del
} 


\section{Balajú}

Dichas carencias técnicas, sin embargo, no son realmente significativas ante el valor testimonial de la imagen. La fotografía demuestra que todo lo contado anteriormente era cierto: el río desbordado, las empalizadas realizadas para poder retirar los despojos que el propio río transporta, la presencia de personas atentas al curso de las aguas para poder localizar los cuerpos y los restos que arrastra. Los editores de El Dictamen fueron bien conscientes de ello y le dedicaron un lugar destacado en la portada del periódico. Se trata probablemente de la imagen más dramática captada del terremoto. Traslada al horror vivido en el lugar de los hechos. Explicita la dureza y la rudeza del momento. Da magnitud al siniestro. Más allá de las palabras, se presenta para suscitar respuestas empáticas en la audiencia. Como Barret apunta, esta ha sido una de las aportaciones que la fotografía históricamente ha logrado: "la fotografía será el testigo del hecho; mucho mejor que el dibujo, comunicará el efecto de conmoción, sorpresa, miedo o lástima que sienten los espectadores que lo han experimentado" (Barret, 1977: 141).

Se ha ejemplificado de forma detallada el conjunto de informaciones sobre el suceso que publicó El Dictamen para poner de manifiesto la persistencia del modelo periodístico basado en el texto dominante hasta finales de los años veinte. En este modelo, las imágenes se contemplan como meras ilustraciones que añaden credibilidad a un relato ya construido, actuando como foto-atestado (Ledo, 1998). A pesar de ello, como se puede comprobar con esta fotografía, la imagen de la empalizada de San Francisco desborda la función meramente testimonial que se le presume. ${ }^{12}$ La fotografía, como se verá, trasciende la función testimonial que le atribuye El Dictamen al circular internacionalmente. Su reubicación pondrá en evidencia la polisemia de las imágenes y su capacidad de mutación significante.

\section{Los efectos del sismo en Xalapa}

A pesar de que el epicentro del terremoto se localizó en Quimixtlán, en el estado de Puebla, aproximadamente a sesenta quilómetros en línea recta de la ciudad de Xalapa, la capital de

río San Francisco. El uso de tramas gruesas, necesario para evitar la acumulación de tinta en la rotativa, provocaba grandes pérdidas de detalle.

${ }^{12}$ Durante las primeras décadas del siglo XX, la fotografía de prensa se delimita a las publicaciones semanales y los magazines (por ejemplo, Gervais y Morel, 2017). La compaginación de fotografías en la prensa diaria, dominada aún por el modelo tipográfico, supone un reto complejo. Las imágenes habituales se reservan para la publicidad, que se distribuye en página previamente a la incorporación de la información. En palabras de Kevin G. Barnhurst y John Nerone, “A diferencia de los semanarios ilustrados inventados para centrarse en las fortalezas particulares y el entusiasmo por las imágenes, los diarios siguieron una larga tradición construida sobre una base de texto. En el periodismo tipográfico, las imágenes eran intrusas. Su entrada en las noticias diarias puede narrarse como una batalla para superar las barreras técnicas" (Barnhurst y Nerone, 2001: 140). 


\section{Balajú}

Veracruz centralizó en gran medida el foco de interés periodístico e informativo, hasta el punto de acuñarse el sobrenombre de temblor de Xalapa para referenciar el episodio sísmico que aconteció en enero de 1920 en esa extensa zona del país. Ciertamente, los desperfectos sufridos en la ciudad fueron menores en comparación con otras poblaciones afectadas, como Teocelo y Cosautlán. Según el recuento efectuado por el Instituto Geológico de México, solamente se lamentaron tres víctimas mortales y diez heridos en Xalapa. ${ }^{13}$ Los daños materiales fueron cuantiosos, como testimonia la solicitud presentada por la cámara de comercio de Xalapa al Gobernador del Estado solicitando la extinción de impuestos durante un año con el fin de poder reedificar la ciudad (El Dictamen, 23 de enero de 1920, p. 1). En acuerdo del 3 de marzo de 1920, el gobernador del estado, el general Cándido Aguilar, comunicó el reparto de fondos a las ciudades afectadas, destinando las mayores cuantías a Jalapa y a Coatepec (60 000 pesos) y a Cosautlán, Teocelo e Ixhuacán (60 000 pesos). El resto de las poblaciones recibieron cantidades muy menores. ${ }^{14}$

\footnotetext{
${ }^{13}$ Nuevamente, los datos que recoge el informe del IGM difieren enormemente de los datos ofrecidos por la prensa. El propio informe lamenta las informaciones ofrecidas por esta, que califica de exageradas y alarmistas: "La prensa de información exageró los daños causados por estos temblores, introduciendo alarma en todo el país, que trascendió al extranjero; pero, sobre todo, propaló conceptos que indujeron al público a formar idea errónea acerca de la naturaleza verdadera del fenómeno" (Salazar, 1922: 9). En cualquier caso, la comisión del IGM llegó a Xalapa el 13 de enero de 1920, diez días después de la catástrofe, cuando las labores de auxilio y de reconstrucción ya se habían iniciado, organizadas principalmente por la Cámara de Comercio de Xalapa. César Luna, en su trabajo sobre los sismos, valida información publicada en la prensa cuando indica que "en Xalapa se cayeron muchas casas, entre ellas la iglesia de los Corazones, el Palacio de Justicia, quedó en ruinas el orfanatorio Francisco I. Madero. Numerosas casas estuvieron por desplomarse. Hubo muchas víctimas entre los escombros" (Luna, 1994: 58-59).

${ }^{14}$ Secretaría de Gobierno del Estado libre y soberano de Veracruz-Llave (1920). Acuerdo indicando la forma en que se distribuirán las cantidades recibidas como donativos y destinado a la reconstrucción de las poblaciones destruidas. Expediente $\mathrm{n}^{\circ}$ 58, Letra A. de Fomento, Trabajo y Agricultura. Archivo General del Estado de Veracruz.
} 


\section{Balajú}
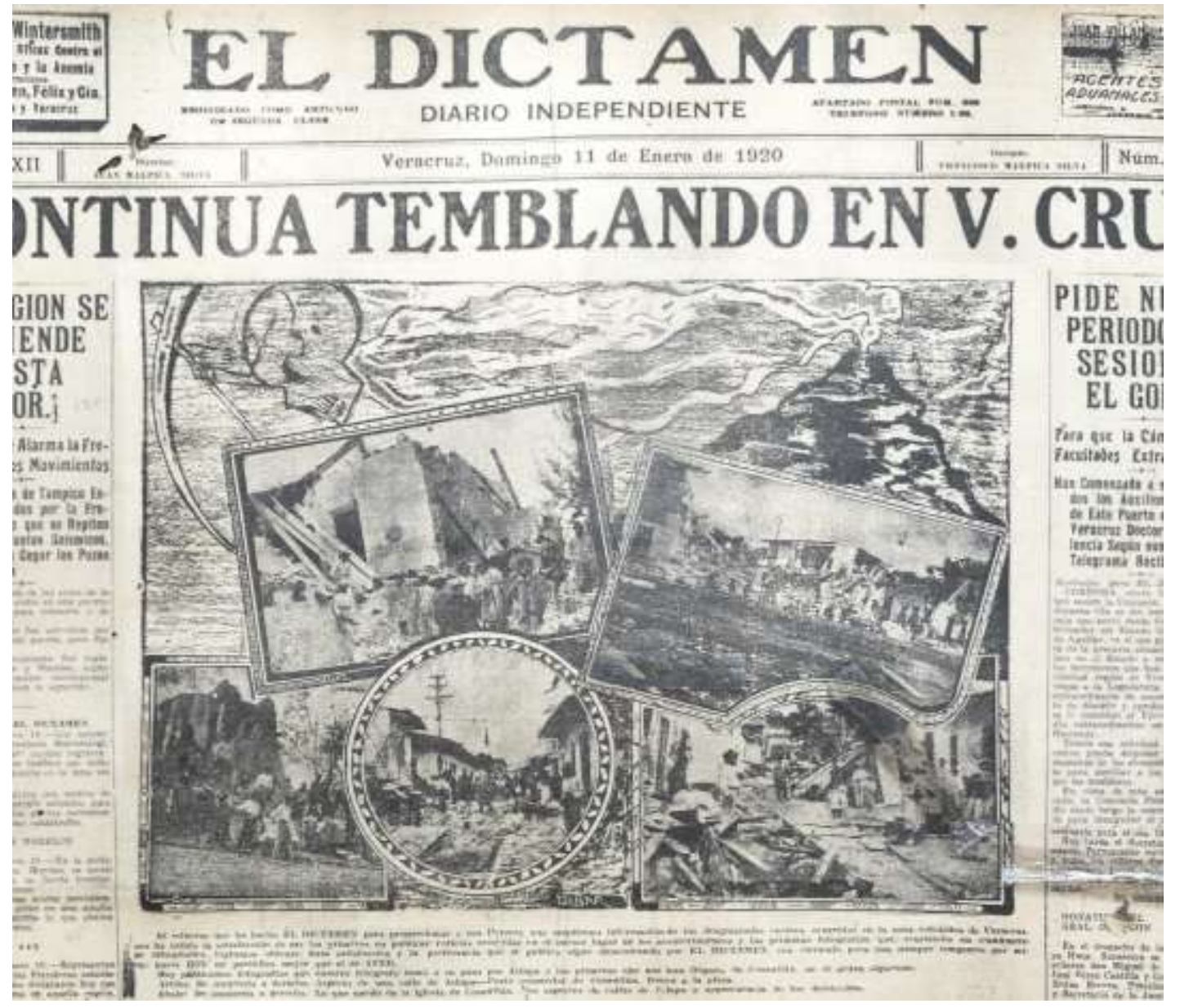

FIGURA 2. Montaje gráfico creado por Urbina a partir de cinco fotografías del terremoto. Fotografías atribuidas a Manuel Jiménez. Fuente: El Dictamen, 11 de enero de 1920, p. 1, Hemeroteca de El Dictamen, Puerto de Veracruz.

El domingo 11 de enero, El Dictamen abrió edición con una composición de cinco fotografías del seísmo, tres de ellas correspondientes a Xalapa y dos a Cosautlán (figura 2). Las fotografías de Xalapa destacan por estar tomadas en las calles; se puede apreciar a los ciudadanos en medio de las ruinas producidas por el desplome de las viviendas. El periódico redactó un breve pie de página: "Aspectos de calles de Jalapa a consecuencia de los derrumbes" (El Dictamen, 11 de enero de 1920, p. 1).

De las tres imágenes sobre Xalapa, en esta investigación solamente se tomará en consideración la que se muestra en la figura 3 porque, como se verá en los siguientes apartados, tuvo un éxito mediático importante. ¿Qué aparece en esta que la hizo sobresalir respecto de las otras? Los derrumbes de Cosautlán fueron mucho mayores que los de Xalapa; sin embargo, la fotografía más reproducida posteriormente en la prensa nacional e internacional no fue ninguna de las obtenidas en dicha población. 


\section{Balajú}

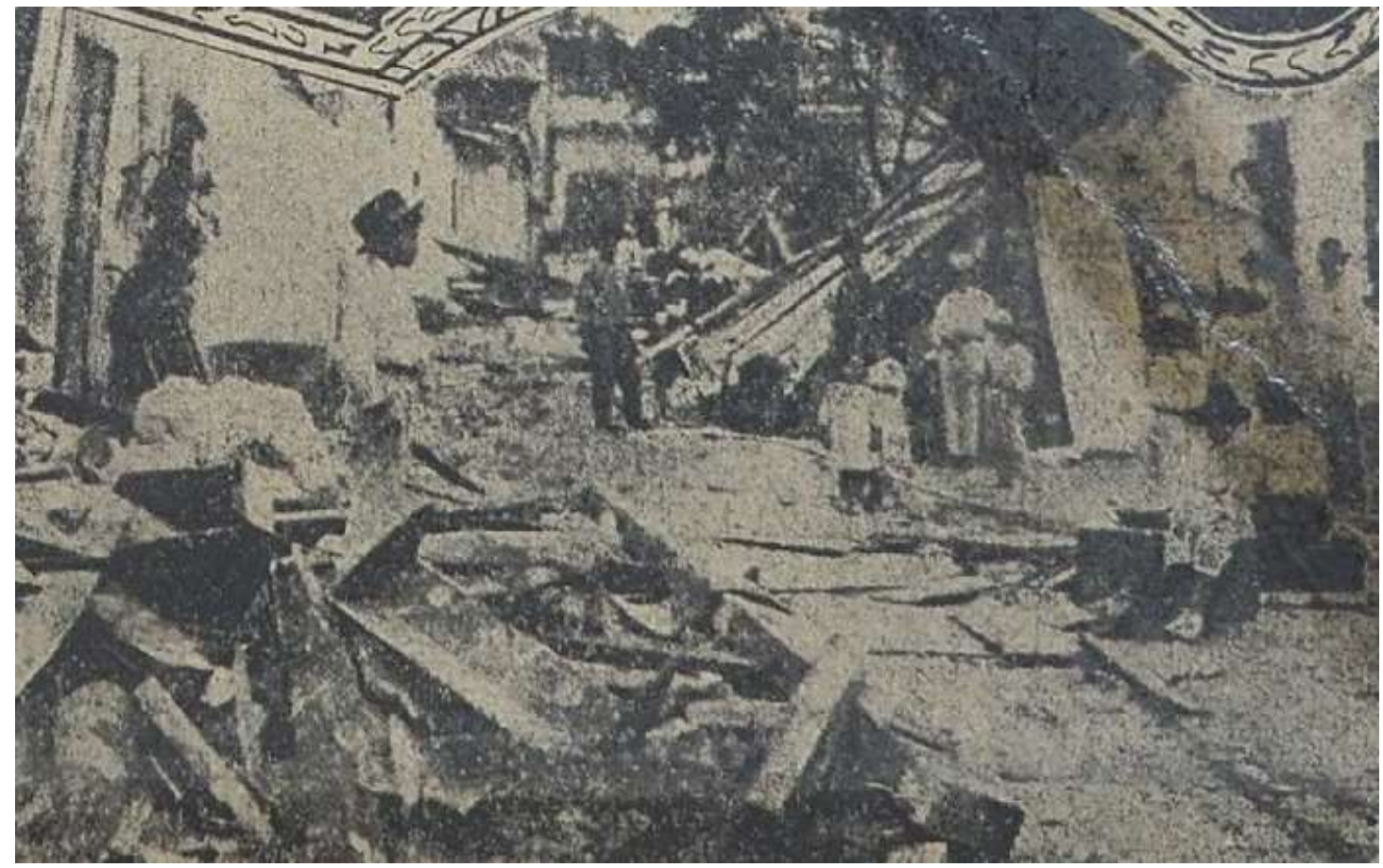

FIGURA 3. Aspectos de calles de Jalapa a consecuencia de los derrumbes. ${ }^{15}$ Fotografía de Manuel Jiménez. Fuente: El Dictamen, 11 de enero de 1920, p. 1, Hemeroteca de El Dictamen, Puerto de Veracruz.

La imagen muestra una composición horizontal dominada por un gran volumen de escombros que se reparte en dos grandes masas y dibuja una diagonal. Una ocupa el primer plano, en la zona izquierda, y la segunda se encuentra en la derecha, fugando hacia el fondo de la imagen. En el centro, apenas se puede reconocer el trazado de la calle. Un pequeño árbol sobresale por detrás de los escombros, como si se tratara de un superviviente del desastre. En los laterales, los vestigios de paredes de casas con ventanas permiten reconocer el entorno urbano, la vecindad. El encuadre no muestra lo suficiente como para constatar si las viviendas afectadas están completamente en ruinas o se sostienen en pie. A diferencia de la fotografía del río San Francisco, los personajes que aparecen en la escena no realizan ninguna labor relacionada con el socorro, la retirada de escombros o la reconstrucción. En la imagen predominan los niños. En el primer término encontramos un niño de perfil, parado, sin hacer nada, con las manos en los bolsillos, observando con posado serio, y quizás con impotencia, el

\footnotetext{
15 A pesar de que El Dictamen tituló las imágenes de forma genérica como "Aspectos de calles de Jalapa a consecuencia de los derrumbes", la fotografía en cuestión no corresponde propiamente a una calle. Se trata del interior de un amplio patio de vecindad que se encontraba en la calle de Allende. A partir de los años cuarenta, el patio paulatinamente se transformó en un callejón para facilitar la circulación de las nuevas colonias al sur de esa zona (información facilitada personalmente por Vicente Espino-Jara, Cronista de Xalapa).
} 


\section{Balajú}

escenario. Otros menores y adultos completan la escena, todos ellos un poco más alejados de la cámara, también quietos, sin hacer o poder hacer nada. Algunos miran a la cámara.

Se trata de una fotografía elocuente. Se pueden apreciar los efectos devastadores del terremoto y percibir la dimensión humana de la catástrofe. La presencia simultánea de las viviendas en ruinas y de los niños permite asociar los contenidos y suponer que numerosas familias se han quedado sin hogar por efecto del sismo. La actitud de los personajes parece reflejar la impotencia y el horror ante la gravedad del suceso. Las personas están y se encuentran en la calle. La fotografía publicada pone de relieve la dimensión social de los acontecimientos: "La fotografía inaugura los mass media visuales cuando el retrato individual se ve sustituido por el retrato colectivo" (Freud, 1983: 96).

El miércoles 7 de enero por la noche se formó en Veracruz la Junta de Socorros, a iniciativa del recién nombrado obispo Rafael Guízar y Valencia, con el fin de recaudar fondos y ayudas para los damnificados. El Dictamen participó en su promoción y gestión: "Aunque EL DICTAMEN no ha abierto ninguna subscripción pública para auxilios de los damnificados por los terremotos [...] varias agrupaciones y particulares nos han hecho depositarios de sumas que destinan al auxilio de las víctimas, para que nosotros las hagamos llegar a su destino" ( $E l$ Dictamen, 8 enero de 1920, p. 1).

El día 9, la portada del diario destacó que "Se han reunido sobre 300.000 pesos para las víctimas" y que "La Junta de Socorros reunió 12.000" (El Dictamen, 9 enero de 1920, p. 1). La nota indicaba las aportaciones procedentes de las subscripciones abiertas por los dos principales periódicos de la Ciudad de México, El Universal y Excélsior. El día 10, de nuevo en portada, convivieron los dos aspectos noticiosos de la catástrofe. Por un lado, los titulares recalcaban la dimensión real del desastre, más excepcional a medida que se obtenían más detalles de las poblaciones afectadas. Por otro lado, se elogiaba la solidaridad de la ciudadanía. Este aspecto, como se ha visto, se inició como un acontecimiento local con la creación de la Junta de Socorros en Veracruz, y tomó, a partir de ese momento, dimensión nacional: "La república entera se apresta a auxiliar a los que quedaron sin hogar" (El Dictamen, 10 de enero de 1920, p. 1).

La publicación de esta fotografía en portada sirve, de nuevo, para testificar el hilo informativo trazado por el periódico durante los últimos días. La imagen del vecindario de Xalapa cubierto de derribos y la presencia de los niños corrobora cuán imprescindible era la reconstrucción y valida la apuesta hecha por los distintos medios de comunicación para 


\section{Balajú}

incentivar y promocionar la solidaridad nacional con los damnificados. ${ }^{16}$ Las fotografías, aún publicadas días después de que se iniciara el relato periodístico sobre los afectados, los desperfectos y la necesidad de solidaridad, permiten ilustrar y dotar de singularidad al discurso periodístico. La calle concreta, el niño concreto, ataviado pulcramente y con sombrero, activan mecanismos de empatía e identificación acordes con los postulados de la fotografía social promovidos pocos años antes por Lewis Hine: "La imagen es un símbolo que nos acerca de inmediato a la realidad [...] La fotografía tiene un realismo añadido propio; tiene una atracción inherente que no se encuentra en otras formas de ilustración [...] El mayor avance en el trabajo social se logrará mediante la popularización del trabajo fotográfico" (Hine, 1909: 355-57).

\section{Otras publicaciones de las fotografías}

El mismo domingo 11 de enero, el periódico Excélsior, de la capital, mostró en la primera página la imagen de la calle (figura 4), con el pie de foto: "Jalapa.- Escombros de edificios desplomados durante las sacudidas del sismo registradas la noche del 3 de enero" (Excélsior, 11 de enero de 1920, p. 1). En el interior, en la página 11, reprodujo la fotografía de la empalizada de San Francisco de las Peñas (figura 5) que El Dictamen había publicado dos días antes. La acompañaba la siguiente leyenda: "El presidente municipal, en unión del pueblo, desalojando la palizada del río S. Francisco. Recogiendo cadáveres” (Excélsior, 11 de enero de 1920 , p. 11).

\footnotetext{
${ }^{16}$ En San Francisco (1906), Messina (1908) y Tokio (1923), la destrucción dará paso a proyectos de reconstrucción nacional auspiciados por el estado (Weisenfeld, 2012). En México, de forma parecida a lo que sucede en Chile, los medios de comunicación liderarán y canalizarán la solidaridad de la ciudadanía, que se convertirá en categoría y valor de identidad nacional (Onetto, 2018).
} 


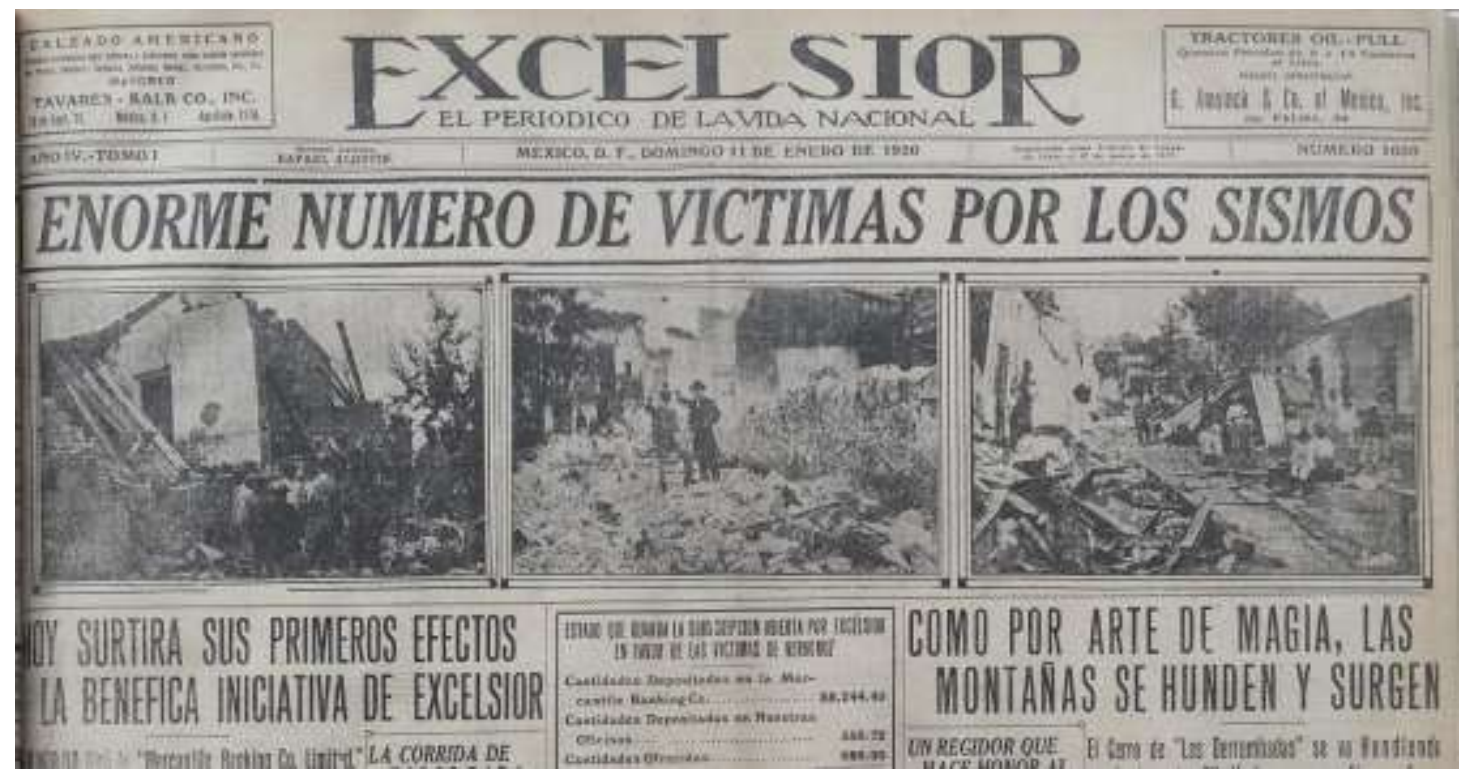

FIGURA 4. Tercera fotografía, a la derecha. Fotografía atribuida a Manuel Jiménez. Fuente: Excélsior, 11 de enero de 1920, p. 1. Hemeroteca de la Biblioteca Miguel Lerdo de Tejada, Ciudad de México.

La portada de Excélsior del día 11 se componía de las tres primeras imágenes tomadas en el lugar de la tragedia. Anteriormente el periódico había publicado gráficos e imágenes de archivo. Se da la singularidad de que todas ellas correspondían a la ciudad de Xalapa. En la misma página se destacaba en un recuadro las cantidades recaudadas en la suscripción abierta en favor de las víctimas de Veracruz: 9484.12 pesos, y daba noticia de un primer envío de 8000 pesos al obispo de Veracruz y presidente de la Junta de Auxilios para su distribución a los damnificados. Las víctimas, los destrozos y la reparación son los elementos clave del discurso que Excélsior asumió liderando la recolecta de fondos y óbolos para los damnificados. Las fotografías de Xalapa servían para ilustrar perfectamente la existencia de víctimas, los habitantes de la ciudad, los cuales aparecían como grupo, como colectivo, pero también como individuos, sobre todo representados por los niños. Como apunta Susanne Leikam: "Desde la invención de la imprenta, los cuerpos humanos en imágenes de terremotos han servido como sismógrafos que indican la intensidad física del temblor de la tierra y los efectos emocionales que lo acompañan” (Leikam, 2019: 485). 


\section{Balajú}

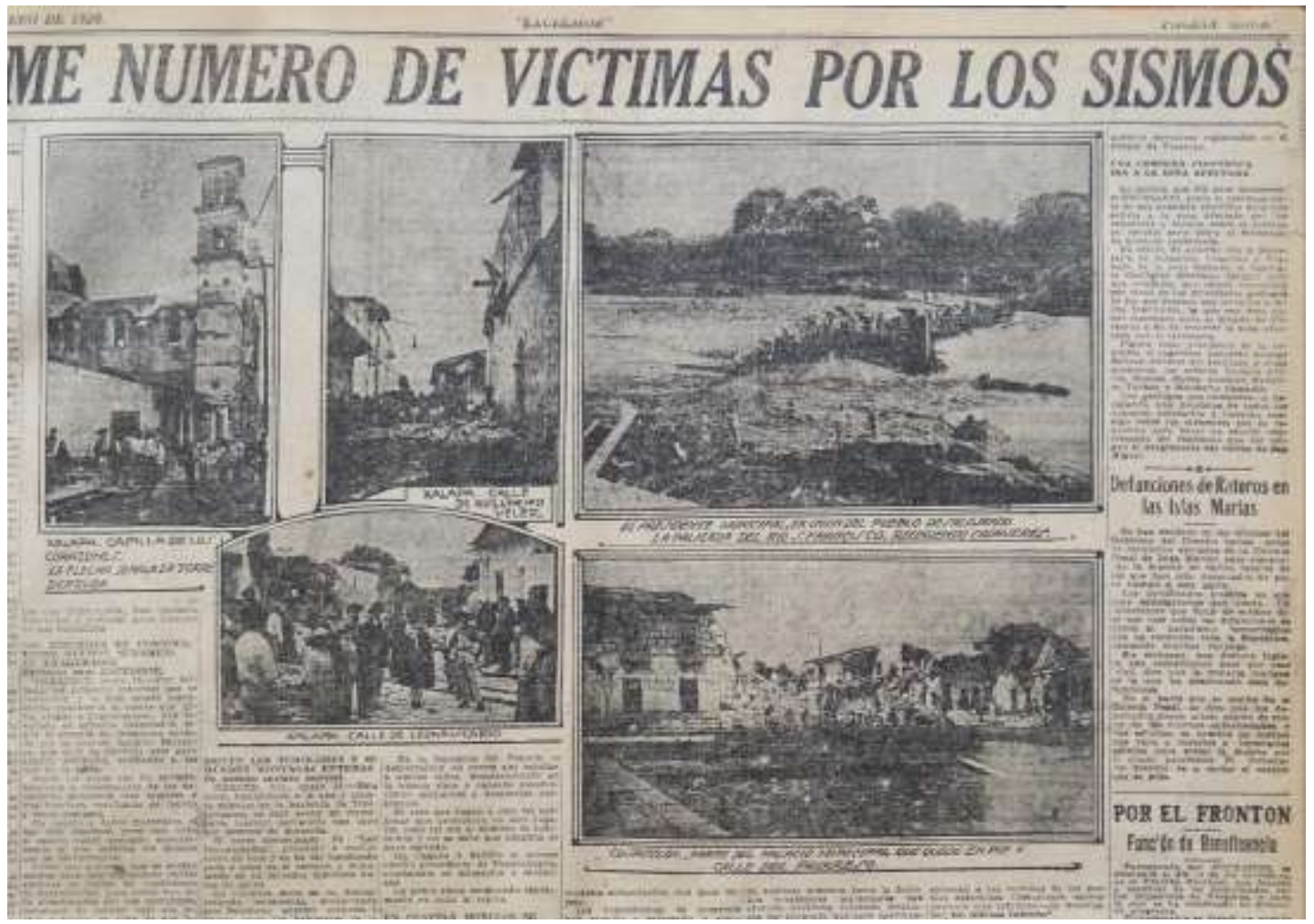

FIGURA 5. Tercera foto derecha, superior. Fotografía atribuida a Manuel Jiménez. Fuente: Excélsior, 11 de enero de 1920, p. 11. Hemeroteca de la Biblioteca Miguel Lerdo de Tejada, Ciudad de México.

El montaje publicado en la página 11 mostraba, además de la imagen de la empalizada en el río, otras tres fotografías de la ciudad de Xalapa. En estas volvían a aparecer ruinas y ciudadanos en la calle en medio de los desperfectos. En la última fotografía del conjunto se podían apreciar los destrozos sufridos en el Palacio Municipal de Cosautlán.

La imagen del rescate de cadáveres actúa en esta composición visual de forma diferente a su edición original en El Dictamen, donde aparecía sola y en portada. Mostrada días más tarde, ubicada en el interior y relacionada con otras imágenes, se modifica la percepción de temporalidad de los acontecimientos. En diálogo con las otras imágenes, el desenlace de los hechos se difumina. Los enormes destrozos conviven con la aparición de nuevos cadáveres y la necesidad de ayuda se presenta más apremiante.

A día 11 de enero, la tarea de retirar cuerpos había disminuido y para la prensa este tema se había convertido en residual. Precisamente, El Dictamen de ese mismo día reportaba el rescate de dos cadáveres en el mar y el desmantelamiento de las empalizadas: "Los trabajos emprendidos para quitar la enorme palizada que impide la corriente del río están muy adelantados gracias a la actividad de las autoridades municipales. Se cree terminar a más tardar dentro de dos días" (El Dictamen, 11 de enero de 1920, p. 8). 


\section{Balajú}

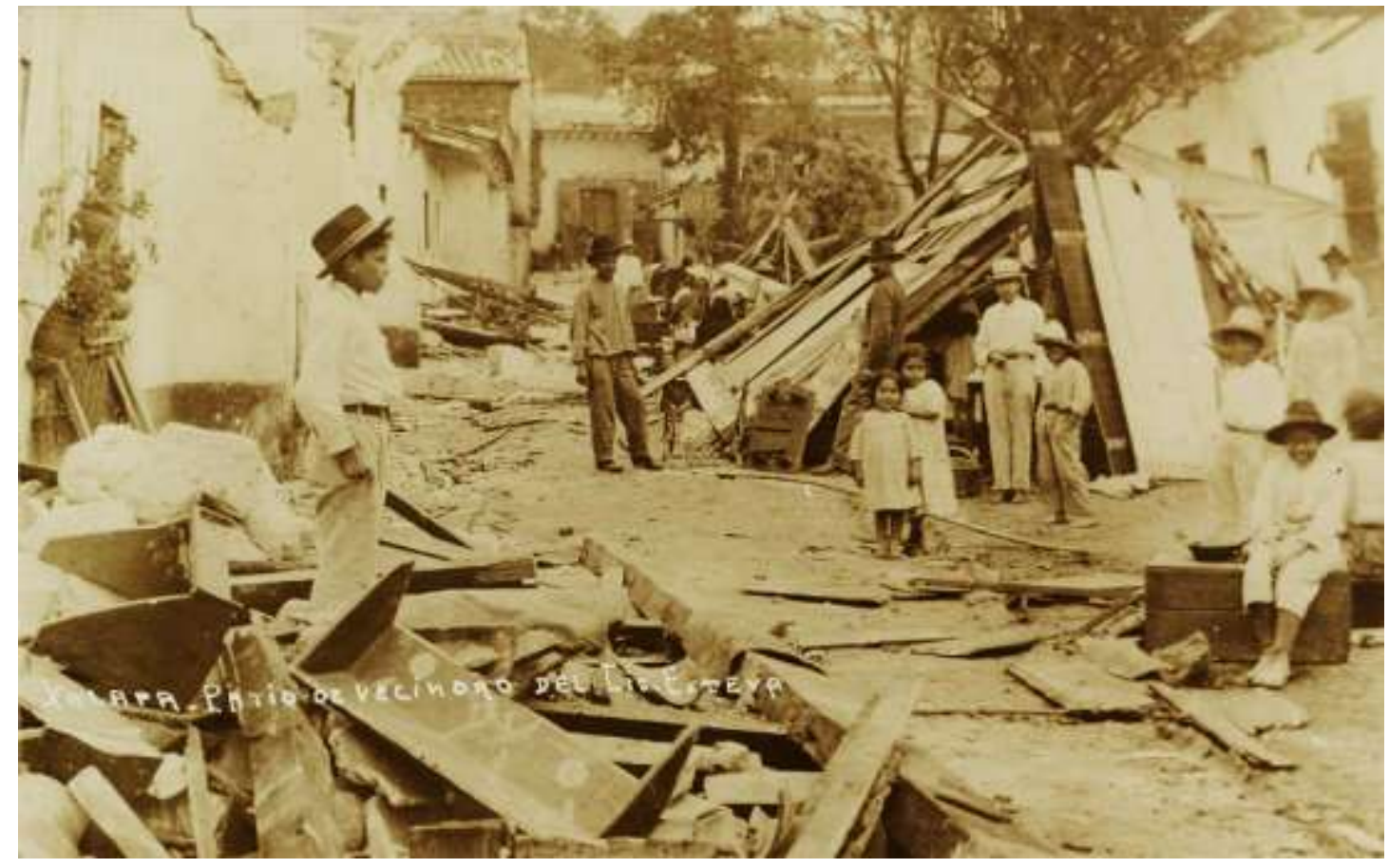

FIGURA 6. Tarjeta postal de Xalapa. Patio de vecindad del Licenciado Esteva. Fotografía atribuida a Manuel Jiménez. Fuente: Fondo AGEV histórico. Colección digital, AGEV.

El uso de la fotografía de los derrumbes de las calles de Xalapa publicada en los periódicos Excélsior y El Dictamen el día 11 de enero de 1920 se expandió más allá de la prensa informativa. Se copió en forma de tarjeta postal y se distribuyó en comercios fotográficos. ${ }^{17}$ Con el cambio de formato, dicha imagen devino un dispositivo excepcional por su calidad visual, puesto que se trataba de una copia de tiraje fotográfico. En ella se pueden apreciar todos los detalles que el procesado de semitonos eliminó de las copias impresas en la prensa. Los niños fascinados mirando al fotógrafo y a la cámara, la postura impasible del niño en primer plano (¿siguiendo las instrucciones del fotógrafo?) vestido elegantemente con sombrero. Se descubre que los tablones, lonas y maderas que ocupan el segundo término de la imagen no son restos de escombros sino una de las barracas construidas para dar cobijo a las personas que perdieron sus viviendas y malvivían en la calle. La copia postal ofrece enormes matices inapreciables en los periódicos y facilita la creación de relatos personales vinculados a los acontecimientos, permitiendo procesos de información horizontales (Guereña, 2005; Wolff y

\footnotetext{
${ }^{17}$ La copia publicada en este artículo se adquirió en Veracruz. Probablemente en el principal establecimiento activo en esa ciudad en esos años, el Estudio Iris: "Las fotografías que salen del Estudio 'Iris' son perfectas, siendo por esto que hoy toda la sociedad Veracruzana prefiere esta casa" (Hernández Palacios, 2010: 113). También existe la posibilidad de que la tarjeta postal se haya comprado en alguno de los comercios fotográficos de Xalapa existentes en ese momento, como Jiménez y hermanos, propiedad de Manuel Jiménez (Ladrón de Guevara, 2010), quien pudiera ser el autor de las imágenes.
} 


\section{Balajú}

Allen, 2005; Milne, 2010). Este tipo de postales fotográficas tenían un tiraje y una distribución reducidos en comparación con las tarjetas postales impresas que colmaban el inmenso mercado de la tarjeta postal (Benson y Vaule, 2004). Cada copia se obtenía por el procedimiento de contacto y era única. Actualmente es imposible saber la cantidad de ejemplares que se efectuaron de esta imagen, ya que no se realizaban registros y generalmente se producían nuevas copias a medida que se iban vendiendo. Probablemente no fueran más que algunas decenas.

La postal incorpora un escueto texto manuscrito a modo de pie: "Xalapa. Patio de vecindad del Lic. Esteva”. Este tipo de leyenda era común en las tarjetas postales. Añadía una breve descripción que permitía codificar mínimamente el contexto de la imagen, suscrita generalmente a la localización de lo que acontecía en la fotografía (Rashkin, 2015). En otros casos, dichas anotaciones otorgaban a los autores cierta licencia para guiar la lectura y expandir los significados de las fotografías. Aquí sorprende lo sucinto del texto, que se limita a la indicación relativamente vaga de la localización de los acontecimientos mostrados en la toma. ${ }^{18}$ No constan ni la fecha ni la autoría. No se da tampoco referencia alguna sobre la causa de los destrozos, sobre el seísmo ni sobre sus devastadores efectos. En el anverso figuran estampados de fábrica los textos y el logotipo del papel Kodak AZO: "Post Card; Correspondence; Address; Place stamp here".

\section{Trayectoria internacional}

En los días posteriores a su publicación en México, las dos fotografías objeto de estudio aparecieron publicadas en la prensa internacional de forma conjunta. Varios periódicos norteamericanos las reprodujeron de forma destacada. Este es el caso, por ejemplo, del Richmond Palladium, periódico de Richmond, Indiana, que el día 23 de enero de 1920 presentó en la portada un recuadro con ambas imágenes. Con un formato prácticamente idéntico y un

\footnotetext{
${ }_{18}$ Dos elementos llaman especialmente la atención en este breve texto. El primero es el uso del topónimo de Xalapa escrito con la letra "X", una reivindicación polémica que no se reguló hasta la década de 1970 (Decreto 325 del 4 de septiembre de 1978, Congreso de Veracruz), lo cual permite suponer que el autor del texto era una persona xalapeña conocedora de la controversia creada con la grafía del topónimo de la ciudad. En segundo lugar, sorprende la grafía de la letra " $n$ " escrita de forma invertida. Este tipo de errores eran relativamente frecuentes en el rotulado de tarjetas postales, ya que el texto se escribía directamente sobre el negativo. Consecuentemente, quedaba invertido en la copia fotográfica. La inseguridad en el trazo y dichas erratas dan pie a aventurar que la persona que rotuló esa imagen no era alguien con demasiada práctica en la tarea.
} 


\section{Balajú}

texto muy parecido, dichas fotografías se publicaron una semana después, el 29 de enero, en el Gran Forks Herald, de Gran Forks, Dakota del Norte (figuras 7 y 8).
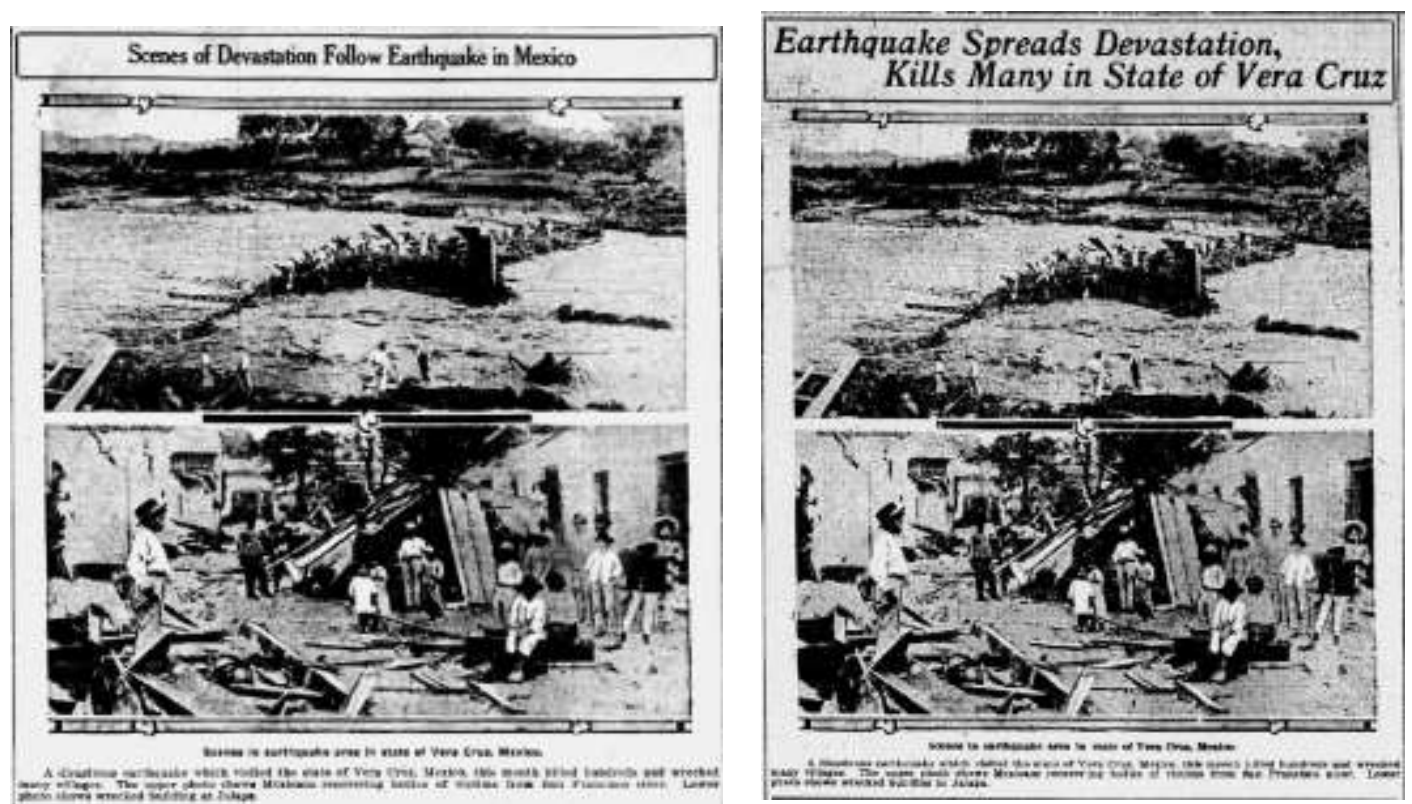

FIGURAS 7 y 8. Reproducción de las dos imágenes del sismo en los periódicos Richmond Palladium, del 23 de enero de 1920, y Gran Forks Herald, del día 29 de enero de 1920, ambos de Estados Unidos. Fuente: Library of Congress.

De hecho, son numerosos los medios informativos impresos que, desde finales de enero y durante los meses de febrero y marzo, dieron razón de la noticia del terremoto de México de 1920 a través de estas dos fotografías publicadas conjuntamente o por separado. Entre otros, el The Ogden Standard, de Utah el 31 de enero; The New Scimitar, de Tennessee, el 3 de febrero; The Hope Pioneer, de North Dakota, el 5 de febrero, The North Platte, de Nebraska, el 6 de febrero; The Prescott Daily News, de Arkansas, el 12 de febrero y el The Chattanooga News, de Tennessee, el 5 de marzo. 


\section{Balajú}

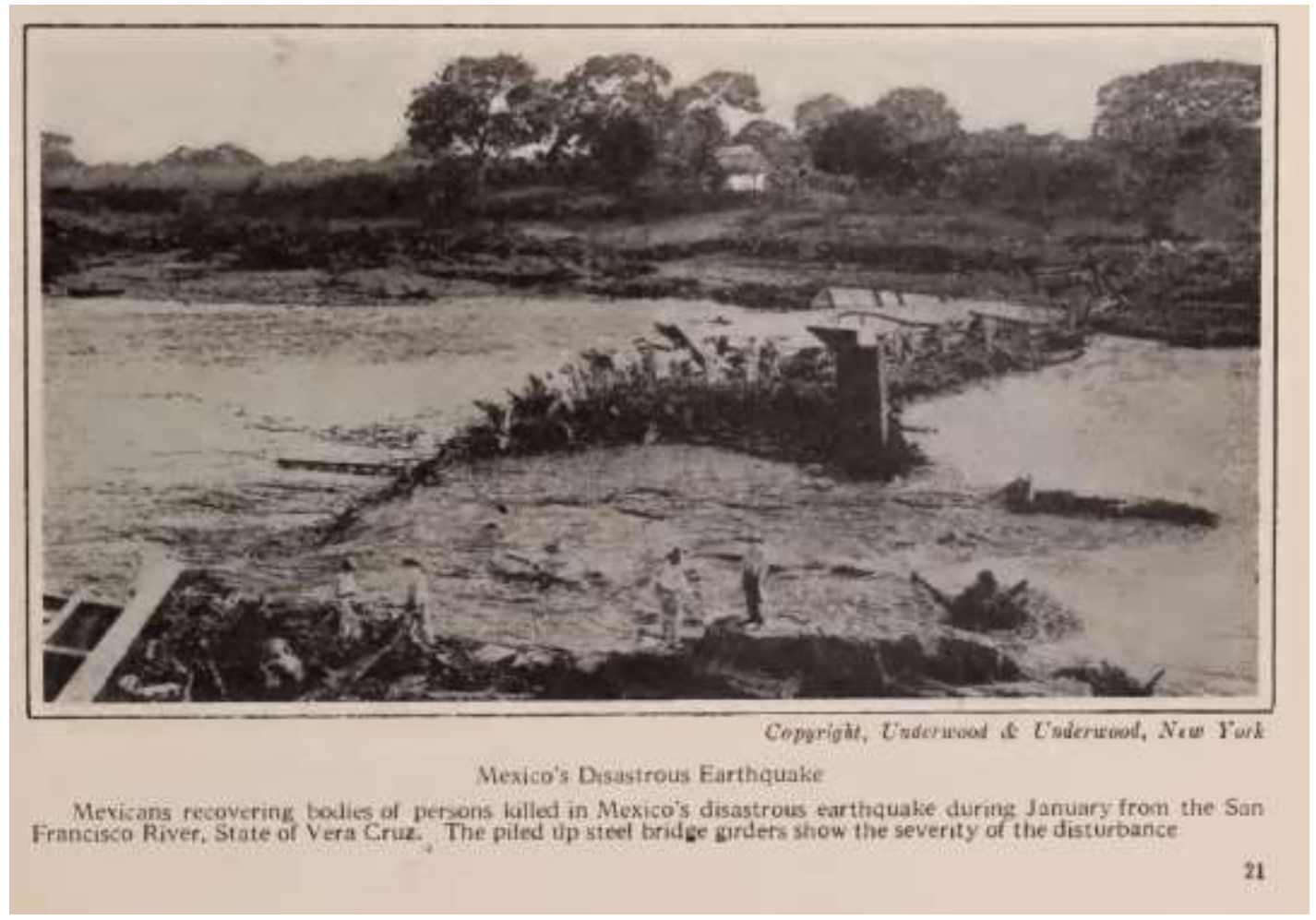

FIGURA 9. Reproducción de la imagen de San Francisco de las Peñas en el Baltimore and Ohio Employees Magazine. Fuente: Baltimore and Ohio Employees Magazine, marzo de 1920, p. 21

El magazín mensual de los empleados ferroviarios de Baltimore y de Ohio, en su número de marzo de 1920, ofrece información que clarifica el recorrido seguido por las fotografías en su periplo norteamericano. En el pie de foto se asigna la autoría de la fotografía a la agencia de noticias fotográficas Underwood \& Underwood, sita en la ciudad de Nueva York, en Estados Unidos de América. La gran calidad y detalle de la impresión permite suponer que el fotograbado se realizó a partir de una copia original del negativo, adquirida por la agencia norteamericana.

Underwood \& Underwood fue una de las principales editoriales de tarjetas postales norteamericanas de finales del siglo XIX e inicios del XX. En la década de 1910 ampliaron sus actividades comerciales e iniciaron la distribución de fotografías de prensa, convirtiéndose muy pronto en la agencia más importante de Nueva York (Keller, 2011; Ritchie, 2019). 


\section{Balajú}

\section{Autoría}

El terremoto de 1920 acontece en un momento de mutación del rol profesional de los fotógrafos de prensa. ${ }^{19} \mathrm{El}$ aumento de imágenes en las páginas de los periódicos empezaba a permitir el reconocimiento de la labor del profesional de la fotografía que proporcionaba las imágenes al periódico. El Universal, de Ciudad de México, por ejemplo, cuando publica imágenes de archivo para ilustrar y ubicar la noticia del temblor no cita la fuente; sin embargo, cuando las imágenes las obtiene el enviado especial del periódico, se incluye su firma. En la edición del día 18 de enero se presentó un amplio reportaje realizado por sus enviados especiales, el periodista Carlos Queirós y el fotógrafo Carlos Muñana. El nombre de Muñana apareció en la cabecera de las tres páginas que ocupaba el reportaje (El Universal, 18 de enero de 1920, pp. $5,7$ y 11$)$

El Dictamen no indica con claridad la autoría de la fotografía del rescate de cadáveres publicada el día 9 de enero ni de las realizadas en Xalapa publicadas el día 11. Como se ha visto, tan solo refieren que se trataba de las primeras imágenes obtenidas en el lugar de los hechos y de la dificultad para obtenerlas. El día 18 de enero, con motivo de la publicación de un amplio reportaje sobre el terremoto, realizado por el fotógrafo del periódico, se incluyó la siguiente nota: "De Ayahualulco e Ixhuacán podemos ofrecer fotografías que tomó nuestro fotógrafo Cepeda, quien llegó hasta allí con la comisión de la Cámara de Comercio que fué [sic] a impartir auxilios" (El Dictamen, 18 de enero de 1920, p. 9). Se trata de Clemente Cepeda, colaborador habitual de El Dictamen.

Dos notas en el diario Excélsior permiten atribuir la autoría tanto de la fotografía de Xalapa como la del río San Francisco que se han analizado en este trabajo. El domingo 11 de enero, en la portada del periódico apareció la siguiente aclaración: "Nuestros grabados. Debido a la galantería de la acreditada casa 'La Rochester', a la que a su vez le han sido enviadas por el inteligente fotógrafo señor Manuel Jiménez, de Jalapa, nos es posible publicar en este número como complemento gráfico de nuestra información, una serie de vistas sacadas de los lugares más rudamente afectados por la catástrofe" (Excélsior, 11 de enero de 1920, p. 1). El

\footnotetext{
${ }^{19}$ En México, la modernización de la prensa (Del Palacio, 2015) y la cobertura fotográfica de la Revolución permitió el advenimiento de un primer fotoperiodismo publicado básicamente en los semanarios ilustrados y en los complementos dominicales de los periódicos. Para Gautreau, se puede "considerar la Revolución como uno de los primeros 'laboratorios fotoperiodísticos' de América Latina" (Gautreau, 2015: 1). Supuso también la creación en 1911 de la Asociación de Fotógrafos de Prensa, iniciativa que aglutinó a Agustín Víctor Casasola, Abraham Lupercio y Antonio Garduño (Villela Flores, 2015). En 1912, Casasola fundó, junto con Gonzalo Herrerías Velasco, la Agencia de Información Fotográfica Herrerías y Casasola (Mraz, 2012).
} 


\section{Balajú}

sábado 17 de enero editaron un reportaje especial sobre el terremoto, en el cual se indicaba de nuevo que el autor de las imágenes era Manuel Jiménez:

Los periódicos de México han venido publicando extensos telegramas sobre la gran catástrofe que se abatió sobre los infortunados habitantes de Veracruz y Puebla; pero en cambio, la información gráfica ha resultado muy deficiente, y a ello se debe que el público no se haya dado cuenta cabal de la magnitud de la hecatombe. EXCELSIOR pretende subsanar hoy esa deficiencia publicando una serie de fotografías tomadas por el señor don Manuel Jiménez en Jalapa, en Teocelo, en Cosautlán y en Barranca Grande, que hablan con elocuencia de lo que se palpa (Excélsior, 17 de enero de 1920, p. 3).

A pesar de que el fotógrafo Manuel Jiméne ${ }^{20}$ no hubiera sido enviado por Excélsior, el periódico asignó a su trabajo el valor de exclusividad y se vanaglorió de poderlo incorporar como colaborador excepcional, por tratarse de uno de los profesionales más reputados de Xalapa.

Es interesante observar este uso incipiente del reconocimiento autoral, así como de las distintas pautas utilizadas por la prensa. Las imágenes de archivo o adquiridas a terceros carecen generalmente de créditos y de declaración de autoría. Son imágenes que se incorporan al fondo editorial del medio y que se podrán reutilizar en futuros artículos periodísticos. Sin embargo, en estos años, el encargo y la publicación de fotografías realizadas por enviados especiales supone una apuesta editorial por parte de los medios, la cual queda reflejada en las páginas de los periódicos. Gracias a estas iniciativas hoy podemos conocer los nombres de los fotógrafos, así como los de los autores de las crónicas enviados a los lugares de los hechos, como sucede en El Dictamen y en El Universal.

\footnotetext{
${ }^{20}$ Manuel Jiménez Rosales fue el mayor de una saga familiar dedicada a la fotografía. Activo desde principios de siglo hasta inicios de la década de 1930, fue fotógrafo del gobierno del estado de Veracruz, entre 1905-1910; fungió también como oficial para la Comisión Geográfica Exploradora (con sede en Xalapa) que era el antecedente histórico del INEGI (instituto de geografía del gobierno federal mexicano). Por los conflictos de la revolución abandonó Xalapa de 1910 a 1913, periodo en que trabajó como fotógrafo en Yucatán. A su regreso, con la ayuda de ilustres personalidades de Xalapa, volvió a instalar su estudio fotográfico en la ciudad y a colaborar con los medios de comunicación de la ciudad, como la revista Ager (Ladrón de Guevara, 2011 y relato personal de EspinoJara, Cronista de Xalapa, 2020).
} 


\section{Balajú}

\section{Conclusiones y limitaciones de la investigación}

En este estudio de caso se ha trazado un amplio recorrido a partir de dos de las primeras fotografías tomadas del terremoto de 1920 en México. La limitación del objeto de estudio se ha mostrado como una eficaz apuesta metodológica que ha facilitado poder transitar de lo singular a lo genérico. La investigación ha permitido la observación de la circulación y la transformación de las imágenes, así como del papel de los medios de comunicación impresa en la construcción del relato visual de las tragedias naturales. También ha dado visibilidad a los incipientes cambios en el rol del fotógrafo de prensa relacionados con el reconocimiento profesional y la autoría, los cuales tuvieron lugar en los inicios de los años veinte. La investigación ha puesto de relieve la permanencia de un sistema periodístico basado en la composición tipográfica en la prensa diaria, a pesar de mostrar incipientes muestras de transformación hacia un modelo basado en la composición visual, aun solamente presente en la prensa ilustrada o en los complementos semanales.

Se puede aventurar que Manuel Jiménez Rosales es el autor de las primeras imágenes sobre el terremoto del 3 de enero en México en los estados de Puebla y Veracruz. Estas fotografías, publicadas inicialmente en El Dictamen de Veracruz, tuvieron un excepcional recorrido en la prensa nacional e internacional. Asimismo, gozaron de continuidad y de perdurabilidad en forma de tarjetas postales que se expidieron en los comercios fotográficos. Las fotografías viajaron de Xalapa a Veracruz y a la Ciudad de México, para posteriormente difundirse por el mundo desde Nueva York, gracias a la intervención de la agencia de noticias fotográficas Underwood \& Underwood.

¿Cómo fue la circulación de esas imágenes? ¿Qué agentes o intermediarios intervinieron? ¿Participaron los periódicos en la difusión internacional de las mismas? ¿Qué costes y beneficios supuso para las agencias y para el autor su comercialización? En la nota publicada por Excélsior sobre las fotografías, se cita la casa comercial La Rochester como intermediaria para la obtención las imágenes. ${ }^{21}$ Se trata del comercio The Rochester Photo Stock House, sito en el número 5 de la calle 16 de Septiembre, de la Ciudad de México. Fue un distribuidor importante de cámaras y de material fotográfico Kodak. Ofrecían también servicio de revelado y de copiado de fotografías. Sus anuncios comerciales aparecían

\footnotetext{
${ }^{21}$ La Rochester fue fundada por Charles Harris, fotógrafo norteamericano. Además de representar los productos de Kodak en Ciudad de México, realizó tirajes de postales y documentó las primeras décadas del siglo XX (Guevara, 2012).
} 


\section{Balajú}

frecuentemente en El Dictamen y en Excélsior. Eran los distribuidores en México del papel Kodak Azo, utilizado en el tiraje de las tarjetas postales. Sin embargo, a pesar de los datos recopilados, no se puede establecer más allá de la hipótesis qué recorrido siguieron las imágenes y qué actores intervinieron en este.

A diferencia del temblor de 1912, conocido como el de Acambay, del cual tan solo el diario El Imparcial publicó algunas fotografías, el terremoto de 1920 contó con una amplia cobertura periodística. Con la participación de numerosos enviados especiales y fotógrafos, se realizaron completos reportajes de la catástrofe, los cuales se publicaron en los principales periódicos locales y nacionales. Este cambio fue posible gracias al proceso de modernización realizado por la prensa mexicana durante la década de 1910, al incorporar maquinaria de linotipia y fotograbado (Del Palacio, 2015). El Dictamen tuvo un relevante papel en este proceso de modernización (Del Palacio, 1997).

Desde la perspectiva de esta investigación, las fotografías del temblor de Xalapa resultan especialmente importantes porque establecen pautas discursivas en un contexto en el cual no existían antecedentes ni referentes visuales. El éxito internacional de las dos imágenes objeto de estudio permite reflexionar sobre el proceso de destilado seguido por editores y agentes para seleccionar, de todo el conjunto de fotografías realizadas, estas dos como representativas del acontecimiento. Establecen con claridad elementos de la narrativa de catástrofes (García Gómez, 2006) al presentar de forma individualizada a las víctimas, en la figura de los niños y, en concreto, en el niño en primer plano que aparece en la imagen de la vecindad del Licenciado Esteva, en Xalapa. La fotografía de la empalizada para el rescate de cadáveres del río San Francisco consigue ilustrar el acontecimiento en su desarrollo, situando a los espectadores dentro del tiempo de los hechos, distinto del momento de la ruina, el recuento de los destrozos y la reconstrucción, común en el resto de las imágenes del temblor. Ambas imágenes contribuyen a ampliar la iconografía de fotografías de catástrofes iniciadas en la prensa a partir de las imágenes de los terremotos de San Francisco y de Messina (Taylor, 2016) y las inundaciones de París (Jackson, 2011). 


\section{Balajú}

\section{Nota final y agradecimientos}

Este trabajo ha sido posible gracias a la inestimable colaboración de personas e instituciones que de forma generosa han contribuido a su realización. Damos las gracias a la doctora Elissa Rashkin, al doctor Homero Ávila Landa y al Centro de Estudios de la Cultura y la Comunicación de la Universidad Veracruzana por acogernos en Xalapa. El doctor Carles Mitjà nos ayudó desinteresada y amablemente en las pesquisas sobre el proceso digital de las imágenes. Mostramos también nuestro agradecimiento al director general, doctor Juan Eloy Rivera Velázquez y al gran equipo del Archivo General del Estado de Veracruz, así como a la generosa amabilidad de la presidenta ejecutiva y directora general, doña Bertha Rosalía Malpica y al equipo de El Dictamen, quienes nos facilitaron acceso a su impresionante archivo. Queremos dedicar un especial y sentido agradecimiento al maestro Vicente Espino Jara, Cronista de Xalapa, quien nos brindó su saber y amistad.

Este trabajo forma parte de los proyectos de I+D+I RTI2018-095714-B-C21 y PID2019-104628RB-100 (MICINN/FEDER), Ministerio de Ciencia, Innovación y Universidades (España).

\section{Referencias}

Fuentes primarias. Artículos en la prensa de la época $A B C$ (España):

“Los terremotos de Méjico”. 9 de enero de 1920, p. 17.

“El fenómeno geológico en Méjico". 11 de enero de 1920, p. 22.

EL DICTAMEN (Puerto de Veracruz):

“Cadáveres recogidos y que eran arrastrados por las aguas". 6 de enero de 1920, p. 1.

"Macabra recolección de cadáveres". 7 de enero de 1920, p. 5.

“Óbolo de la caridad". 8 de enero de 1920, p. 1.

“Después del terror". 8 de enero de 1920, p. 7.

"Se han reunido sobre 300.000 Pesos para las víctimas". 9 de enero de 1920, p. 1.

“La junta de socorros reunió 12.000”. 9 de enero 1920, p. 1.

[Fotografía en portada sin título y texto en pie de foto]. 9 de enero de 1920, p. 1.

"Más de diez mil víctimas". 9 de enero 1920, p. 6.

"La república entera se apresta a auxiliar a los que quedaron sin hogar". 10 de enero de 1920, p. 1. 


\section{Balajú}

[Composición fotográfica en portada sin título y texto en pie de foto]. 11 de enero de 1920, p. 1.

“La extracción de cadáveres". 11 de enero de 1920, p. 8.

"A través de la zona devastada por los temblores. La impresión de muerto enviado especial y lo que vió [sic] la lente de nuestro fotógrafo en los campos de desolación”. 18 de enero de 1920, p. 9.

"Exención de impuestos y el 50\% de las contribuciones, para reedificar Jalapa. En tal sentido, la Cámara de Comercio de aquel lugar se ha dirigido al Gobernador del Estado, pidiendo que se resuelva favorablemente dicha solicitud, por ser justa y necesaria”. 23 de enero de 1920, p. 1.

EXCELSIOR (Ciudad de México):

"Enorme número de víctimas". 11 de enero de 1920, p. 1.

"Nuestros grabados". 11 de enero de 1920, p. 1.

"Enorme número de víctimas por los sismos". 11 de enero de 1920, p. 11.

"Un récord periodístico informativo". 17 de enero de 1920, p. 37.

El FÍGARO, El (España): “La Catástrofe de Veracruz”. 11 de enero de 1920, p. 11.

El IMPARCIAL, El (España): "Los últimos terremotos en Méjico. Espantosos detalles". 11 de enero de 1920, p. 2.

LA PRENSA (Estados Unidos): "Siguen haciendo víctimas los temblores y aumentando los sufrimientos de los habitantes de la zona que han azotado. A siete mil se hace ascender el número de muertos que ha habido". 11 de enero de 1920, p. 1.

TUCSONENSE, El (Estados Unidos): "El valle de la muerte", 13 de enero de 1920, p. 1.

UNIVERSAL, El (Ciudad de México): "Nuestra información gráfica de los temblores". 18 de enero de 1920, pp. 5, 7 y 11.

Fuentes primarias. Informes

FLORES, Teodoro (1922). "Efectos sobre las construcciones", Boletín del Instituto Geológico de México, 38: 30-36.

SALAZAR SALINAS, Leopoldo (1922). "Introducción”. Boletín del Instituto Geológico de México, 38: 5-8. 


\section{Balajú}

SALAZAR SALINAS, Leopoldo, Teodoro Flores, Manuel Muños Lumbier, Lewis A. Bond y Heriberto Camacho (1922). "Memoria relativa al terremoto mexicano del 3 de enero de 1920”. Boletín del Instituto Geológico de México, 38.

\section{Fuentes secundarias}

AYALA FLORES, Hubonor (2019). "El sismo del 3 de enero de 1920. Reacciones y acciones del Estado, la Iglesia y la sociedad civil”, en M. D. Lorenzo, M. Rodríguez y D. Marcilhacy (coords.), Historiar las catástrofes. Ciudad de México y París: UNAM/Lettres Sorbonne Université, 93-122.

BARNHURST, Kevin G. y John Nerone (2001). The Forms of News. A History. Nueva York, Londres: The Guilfrod Press.

BARRET, André (1977). Les premiers reporters photographes, 1848-1914. París: Duponchelle.

BENSON, Richard y R. B. Vaule (2004). As We Were: American Photographic Postcards, 1905-1930. Boston: David R Godine Publisher.

CONGRESO DE VERACRUZ. (1978). Decreto 325 del 4 de septiembre de 1978, Congreso de Veracruz.

ESCORZA-RODRÍGUEZ, Daniel (2015). “Arte y fotografía en la prensa mexicana. La primera exposición de arte de los fotógrafos de prensa en 1911”. ORDA, L'Ordinaire des $\quad$ Amériques, $219 . \quad$ http://journals.openedition.org/orda/2143; https://doi.org/10.4000/orda.2143

FIGUEROA, Jesús (1970). Sismos ocurridos en la república mexicana. Ciudad de México: UNAM-Instituto de Ingeniería.

FREUD, Gisèle (1983). La fotografía como documento social. Barcelona: Gustavo Gili.

GARCÍA GÓMEZ, Andrés (2006). "La estructura narrativa de sucesos catastróficos en los medios de comunicación”. I Jornada sobre gestión de crisis. A Coruña: Universidade da Coruña, 125-134.

GAUTREAU, Marion (2015). "La fotografía de la Revolución mexicana: ¿el nacimiento de un fotoperiodismo mexicano?" ORDA, L'Ordinaire des Amériques, 219. https://doi.org/10.4000/orda.2093

GERVAIS, Thierry y Gaëlle Morel (2017). The Making of Visual News: A History of Photography in the Press. Londres: Bloomsbury Academic. 


\section{Balajú}

GUEREÑA, Jean-Louis (2005). "Imagen y memoria. La tarjeta postal a finales del siglo XIX y principios del siglo XX”, Berceo, 149, 35-58.

GUEVARA ESCOBAR, Arturo. (2012). La tarjeta postal en México. http://losprotagonistastarjetaspostales.blogspot.com/2012/01/letra-r-fotografos-y-productores-de.html

HERNÁNDEZ PALACIOS, Esther (coord.) (2010). Creadores veracruzanos. Diez semblanzas. México: Comisión Organizadora del Estado de Veracruz de Ignacio de la Llave para la Conmemoración del Bicentenario de la Independencia Nacional y del Centenario de la Revolución Mexicana/Secretaría de Educación del Estado de Veracruz/Gobierno del Estado de Veracruz/Universidad Veracruzana.

HICKS, Wilson (1952). Words and Pictures. An Introduction to Photojournalism. Nueva York: Harper \& Brothers.

HINE, Lewis W. 1909. "Social Photography; How the Camera May Help in the Social Uplift", en A. Johnson (ed.), Proceedings of the National Conference of Charities and Correction at the Thirty-sixth Annual Session held in the City of Buffalo. Nueva York, 9-16 de junio de 1909, pp. 355-59. Fort Wayne, IN: Press of Fort Wayne.

JACKSON, Jeffrey H. (2011). "Envisioning Disaster in the 1910 Paris Flood", Journal of Urban History, 37 (2): 176-207.

KELLER, Ulrich (2011). "Early Photojournalism”, David Crowley y Paul Heyer (eds.), Communication in History: Technology, Culture, Society. Nueva York: Routledge, 144-52.

LADRÓN DE GUEVARA, Jaime-Darío (coord.) (2010). Xalapa: legado fotográfico de Manuel Jiménez Rosales. Ciudad de México y Xalapa: Comisión para la Conmemoración del Bicentenario de la Independencia Nacional y del Centenario de la Revolución Mexicana/Instituto Veracruzano de Cultura/ S y G Editores.

LEDO, Margarita (1998). Documentalismo fotográfico. Madrid: Cátedra.

LERMO SAMANIEGO, Javier, et al. (1995). Efectos de sitio en la ciudad de Xalapa, Veracruz, México. Ciudad de México: Instituto de Ingeniería, UNAM.

LEIKAM, Susanne (2019). "Of Human Seismographs: The Multifaceted Roles of Pictures in the Meaning Making of Earthquakes". Open Cultural Studies, 3, 485-493.

LUNA BAUZA, César (1994). Sismos en el estado de Veracruz. México: Editora del Estado de Veracruz- Llave. 


\section{Balajú}

MALDONADO VALERA, Acacia Ligia (2005). Manuel Ramos en la prensa ilustrada capitalina de principios del siglo XX: 1897-1913. Un acercamiento a los antecedentes del fotoperiodismo en México. Tesis doctoral, Ciudad de México: UNAM.

MILNE, Esther (2010). Letters, Postcards, Email: Technologies of Presence. Nueva York: Routledge.

MORA GONZÁLEZ, Ignacio y José L. Murrieta Hernández (septiembre-diciembre 1995). "Sismos que han afectado al estado de Veracruz", La Ciencia y el Hombre, 35-74.

MRAZ, John (2012). Photographing the Mexican Revolution: Commitments, Testimonies, Icons. Austin: University of Texas Press.

ONETTO, Mauricio (2018). Discursos desde la catástrofe. Prensa, solidaridad y urgencia en Chile, 1906-2010. Santiago de Chile: Acto.

OROZCO y BERRA, Juan, (1887). "Efemérides séismicas mexicanas", Memorias de la Sociedad Científica "Antonio Alzate". Tomo 1, 303-357.

PALACIO, Celia del (1997). “El nacimiento del periodismo moderno en Veracruz”, Sotavento, (2): 113-130.

PALACIO, Celia del (2015). Pasado y presente: 220 años de prensa veracruzana (1795-2015). Xalapa: Universidad Veracruzana.

PEREYRA DÍAZ, Domitilo, José Antonio Agustín Pérez-Sesma y María del Rocío Salas Ortega (2010). "Hidrología”, en Florescano, Enrique y Juan Ortiz-Escamilla (coords.), Atlas del patrimonio natural, histórico y cultural de Veracruz. México: Gobierno del Estado de Veracruz/Comisión del Estado de Veracruz para la Conmemoración de la Independencia Nacional y la Revolución Mexicana/Universidad Veracruzana, 85-122.

RAMÍREZ R., Fernanda (28 de diciembre de 2019). "El terremoto que sacudió hace 100 años a Veracruz y Puebla", El Universal, https://www.eluniversal.com.mx/cultura/elterremoto-que-sacudio-hace-100-anos-veracruz-y-puebla

RASHKIN, Elissa (2015). Atanasio D. Vázquez, fotógrafo de la posrevolución en Veracruz. Xalapa: Instituto Veracruzano de Cultura/Conaculta.

RIEGO-AMÉZAGA, Bernardo (2010). "Una revisión del valor cultural de la tarjeta postal ilustrada en el tiempo de las redes sociales", Fotocinema. Revista científica de cine y fotografía, 1, 3-18.

RITCHIE, Jordan (2019). Underwood and Underwood Company: Early Twentieth Century Pioneers of American Photojournalism. Tesis de maestría, Universidad de Maryland. 


\section{Balajú}

SINGH, Shri K. y Mario Ordaz (1994). "Sismicidad y movimientos fuertes en México: Una visión actual”, Cuadernos de Investigación, 18, 35-74. Ciudad de México: Centro Nacional de Prevención de Desastres (Cenapred).

STAKE, Robert E. (1995). The Art of Case Study Research. Thousand Oaks, Londres, Nueva Delhi: Sage.

SUÁREZ, Gerardo (1991). "El sismo de Jalapa del 3 de enero de 1920", Revista de Ingeniería Sísmica, 42: 3-15, https://doi.org/10.18867/RIS.42.290

SUGAWARA, Masae (1987). "Notas sobre los sismos mexicanos en el siglo XVI", Históricas. Boletín del Instituto de Investigaciones Históricas de la UNAM, 22, 3-18.

TAYLOR, William M. (2016). “Assembling Ruin: Rubble Photography of the 1908 Messina Earthquake", Transformations. Journal of Media, Culture \& Technology, 28, http://www.transformationsjournal.org/wpcontent/uploads/2016/12/Taylor_Transformations28.pdf

VILLELA FLORES, Samuel L. (2015). "El fotoperiodismo en la Revolución mexicana", ORDA, L'Ordinaire des Amériques, 219, https://doi.org/10.4000/orda.2325

WEISENFELD, Gennifer (2012). Imaging Disaster. Tokyo and the Visual Culture of Japan's Great Earthquake of 1923. Berkeley: University of California Press.

WOLFF, Laetitia y Todd Allen (eds.) (2005). Real Photo Postcards: Unbelievable Images from the Collection of Harvey Tulcensky. Nueva York: Princeton Architectural Press.

YIN, Robert K. (2013). Case Study Research: Design and Methods. 5a. ed., Thousand Oaks, Londres, Nueva Delhi: Sage. 